\title{
POLR2A Gene
}

National Cancer Institute

\section{Source}

National Cancer Institute. POLR2A Gene. NCI Thesaurus. Code C20661.

This gene plays a role in DNA-dependent transcription of RNA. 